\title{
Rapid and long-term effects of water deficit on gas exchange and hydraulic conductance of silver birch trees grown under varying atmospheric humidity
}

Arne Sellin*, Aigar Niglas, Eele Õunapuu-Pikas and Priit Kupper

\begin{abstract}
Background: Effects of water deficit on plant water status, gas exchange and hydraulic conductance were investigated in Betula pendula under artificially manipulated air humidity in Eastern Estonia. The study was aimed to broaden an understanding of the ability of trees to acclimate with the increasing atmospheric humidity predicted for northern Europe. Rapidly-induced water deficit was imposed by dehydrating cut branches in open-air conditions; long-term water deficit was generated by seasonal drought.

Results: The rapid water deficit quantified by leaf $\left(\Psi_{L}\right)$ and branch water potentials $\left(\Psi_{B}\right)$ had a significant $(P<0.001)$ effect on gas exchange parameters, while inclusion of $\Psi_{B}$ in models resulted in a considerably better fit than those including $\Psi_{L}$, which supports the idea that stomatal openness is regulated to prevent stem rather than leaf xylem dysfunction. Under moderate water deficit $\left(\Psi_{\mathrm{L}} \geq-1.55 \mathrm{MPa}\right)$, leaf conductance to water vapour $\left(g_{\mathrm{L}}\right)$, transpiration rate and leaf hydraulic conductance $\left(K_{\mathrm{L}}\right)$ were higher $(P<0.05)$ and leaf temperature lower in trees grown in elevated air humidity $\left(\mathrm{H}\right.$ treatment) than in control trees $\left(\mathrm{C}\right.$ treatment). Under severe water deficit $\left(\Psi_{\mathrm{L}}<-1.55 \mathrm{MPa}\right)$, the treatments showed no difference. The humidification manipulation influenced most of the studied characteristics, while the effect was to a great extent realized through changes in soil water availability, i.e. due to higher soil water potential in $\mathbf{H}$ treatment. Two functional characteristics $\left(g_{L}, K_{\mathrm{L}}\right)$ exhibited higher $(P<0.05)$ sensitivity to water deficit in trees grown under increased air humidity.
\end{abstract}

Conclusions: The experiment supported the hypothesis that physiological traits in trees acclimated to higher air humidity exhibit higher sensitivity to rapid water deficit with respect to two characteristics - leaf conductance to water vapour and leaf hydraulic conductance. Disproportionate changes in sensitivity of stomatal versus leaf hydraulic conductance to water deficit will impose greater risk of desiccation-induced hydraulic dysfunction on the plants, grown under high atmospheric humidity, in case of sudden weather fluctuations, and might represent a potential threat in hemiboreal forest ecosystems. There is no trade-off between plant hydraulic capacity and photosynthetic water-use efficiency on short time scale.

Keywords: Betula pendula, Branch water potential, Climate change, Hydraulic conductance, Leaf water potential, Net photosynthesis, Silver birch, Stomatal conductance, Water-use efficiency

\footnotetext{
* Correspondence: arne.sellin@ut.ee

Institute of Ecology and Earth Sciences, University of Tartu, Lai 40, Tartu 51005, Estonia
}

\section{() Biomed Central}

(c) 2014 Sellin et al.; licensee BioMed Central Ltd. This is an Open Access article distributed under the terms of the Creative Commons Attribution License (http://creativecommons.org/licenses/by/2.0), which permits unrestricted use, distribution, and reproduction in any medium, provided the original work is properly credited. The Creative Commons Public Domain Dedication waiver (http://creativecommons.org/publicdomain/zero/1.0/) applies to the data made available in this article, unless otherwise stated. 


\section{Background}

Global warming is accompanied by changes in atmospheric water vapour content and precipitation rate, although there will be pronounced regional differences in their magnitude and direction [1]. Over a period from 1900 to 2005 precipitation has significantly increased in northern Europe and continuation of this trend with larger increase in the frequency than in the magnitude of precipitation is predicted from climatic models. Climate change scenarios predict by the end of the century increases in air temperature by $3.5-$ $5^{\circ} \mathrm{C}$ and precipitation by $5-30 \%$ in boreal and northern temperate regions of Europe [2,3]. Increase in atmospheric relative humidity $(\mathrm{RH})$, the inevitable result of more frequent rainfall events, will reduce water loss through transpiration $[4,5]$, and affect both the delivery of nutrients to root absorbing surface and nutrient uptake by trees due to diminished water fluxes through the vegetation $[6,7]$.

On the other hand, climate extremes including heat waves and droughts across Europe are projected to become more frequent and enduring over the 21 st century $[1,8]$. Because trees have adapted to local average climatic conditions, extreme events have consequences on forest health and productivity across site conditions $[9,10]$. Plants growing in humid air have less effective stomatal control over transpirational water loss $[4,11,12]$ and demonstrate higher vulnerability to xylem cavitation, i.e. have narrow hydraulic safety margin [13,14]. In addition, Okamoto et al. [15] demonstrated that high air humidity induces abscisic acid (ABA) 8 '-hydroxylase in stomata and vasculature, followed by the reduction of ABA levels - a plant hormone, which promotes stomatal closure under water deficit [16].

Water deficit decreases stomatal conductance before leaf water potential $\left(\Psi_{\mathrm{L}}\right)$ falls below critical values, to avoid adverse consequences on leaf tissues (dehydration of protoplasm) and water transport system (hydraulic dysfunction through runaway xylem cavitation). However, the mechanisms by which stomata respond to and control $\Psi_{\mathrm{L}}$ are still unclear $[14,17]$. The classical view suggests that a primary signal of water shortage is $\mathrm{ABA}$, produced by roots situated in dry soil and transported to shoots [18]. As a result, a considerable time lag is expected in the response of stomata to changing soil water status. Soil drying concentrates ABA in both the xylem sap and leaves [19-21]. This is followed by water efflux from guard cells and stomatal closure [22]. Stricter stomatal control leads to increasing short-term (intrinsic water-use efficiency [23]) and long-term water-use efficiency (carbon isotope discrimination [24]).

In Arabidopsis, shoot vascular tissues appear to be a major site of ABA biosynthesis and suggest tissueautonomous ABA synthesis in addition to its longdistance root-to-shoot movement [16,25]. Bauer et al. [26] report that guard cells possess the entire ABA biosynthesis pathway and that cell-autonomous synthesis is sufficient for stomatal closure. Thus, effects of fast changes in leaf water status do not involve chemical signals from roots, but rather are predominantly hydraulic $[22,27,28]$. Guard cells respond to changes in $\Psi_{\mathrm{L}}$ either directly or via a signal generated close by [29]. Stomatal closure, in turn, will increase stomatal limitation to photosynthesis. At severe water deficit, efficiency of photosystem II will decrease as well [12,30,31] further impelling decline of $\mathrm{CO}_{2}$ assimilation.

The structure and function of the water transport system govern the productivity and survival of land plants because the vascular architecture places a physical limit on plant functioning $[29,32]$. Therefore, the water pathway from the soil-root interface to the sites of evaporation in leaves is critical to maintain leaf water status and hold stomata open, keeping a positive carbon budget. Water deficit will induce cavitation of xylem elements in roots, stems and leaf veins $[10,33,34]$, thereby reducing water supply to foliage and amplifying water deficit effects on stomatal conductance and photosynthetic performance. Tissue dehydration also impacts aquaporin (AQP) expression controlling hydraulic conductance of the leaf symplastic compartment [35]. Furthermore, as the concentration of $\mathrm{ABA}$ increases in the xylem, AQP activity in the bundle sheath cells is downregulated, thereby reducing water flow into the leaf as demonstrated by Shatil-Cohen et al. [21].

We analysed the impact of water deficit on plant water status, gas exchange and hydraulic conductance on saplings of silver birch (Betula pendula Roth) under artificially manipulated air humidity in field conditions. Silver birch is distributed widely over almost all of Europe, and in northern Europe it is among the most important commercial tree species. Because trees growing in moist atmosphere experience less water loss and have higher stomatal openness, we hypothesize that physiological characteristics in trees acclimated to higher humidity exhibit higher susceptibility to rapidly-induced water deficit. The primary aim of this study was to test this hypothesis experimentally. Secondly we tested whether the putative trade-off between plant hydraulic capacity and water-use efficiency (WUE) is observable on a short time scale. We aimed this study to broaden the understanding of the ability of trees to acclimate with the increasing atmospheric humidity predicted for northern Europe.

\section{Results}

\section{Effects of air humidification and rapidly-imposed water deficit}

The air humidification caused a decrease of up to $10 \%$ in atmospheric water vapour pressure deficit (VPD) during the misting application (Figure 1). ANCOVA revealed that the humidification treatment influenced $(P<0.05)$ most of the studied characteristics (Table 1). The strongest effects were observed for leaf conductance to water vapour $\left(g_{\mathrm{L}}\right)$ and leaf water potential $\left(\Psi_{\mathrm{L}}\right)$, whereas leaf temperature 


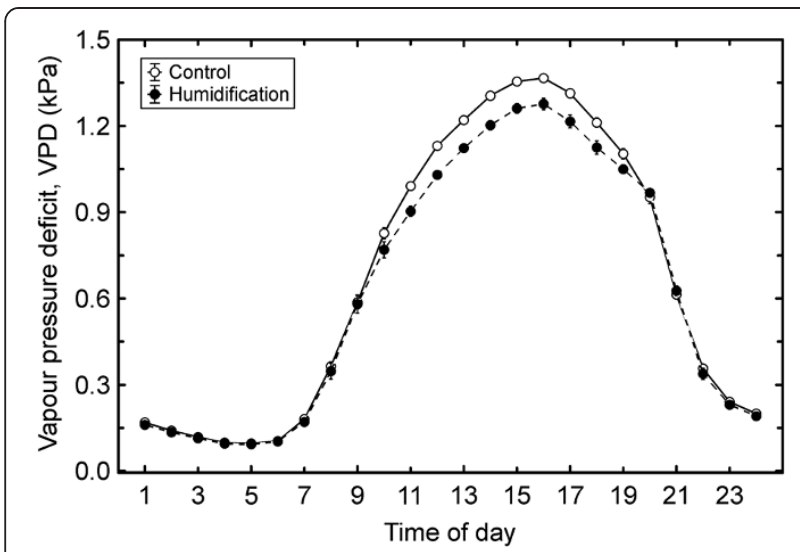

Figure 1 Daily variation of mean atmospheric water vapour pressure deficit (VPD) in June and July 2010. The error bars denote S.E.

$\left(T_{\mathrm{L}}\right)$, ratio of intercellular to ambient $\mathrm{CO}_{2}$ concentrations $\left(C_{\mathrm{i}} / C_{\mathrm{a}}\right)$, net photosynthetic rate $\left(A_{\mathrm{n}}\right)$ and intrinsic water-use efficiency (IWUE) remained unaffected by the manipulation. The rapidly-induced water deficit, quantified by leaf $\left(\Psi_{\mathrm{L}}\right)$ or branch water potential $\left(\Psi_{\mathrm{B}}\right)$, had a highly significant
$(P<0.001)$ effect on all studied parameters. Except for leaf hydraulic conductance, $K_{\mathrm{L}}$, inclusion of $\Psi_{\mathrm{B}}$ into the analysis model resulted in a considerably better fit than inclusion of $\Psi_{\mathrm{L}}$. An analysis of sensitivity of the physiological parameters to changes in plant water status $\left(\mathrm{d} x / \mathrm{d} \Psi_{\mathrm{B}}\right)$, estimated by slopes of the corresponding linear regressions, revealed that almost all variables of trees grown under elevated atmospheric humidity ( $\mathbf{H}$ treatment) tended to respond more sensitively to water deficit. However, in only two cases the corresponding slopes differed significantly between the treatments (Figure 2): $g_{\mathrm{L}}(P<0.05)$ and $K_{\mathrm{L}}(P<0.01)$. In order to compare the $g_{\mathrm{L}}$ and $K_{\mathrm{L}}$ responses to each other, we normalised the absolute values with corresponding means and analysed sensitivity of the normalised $g_{\mathrm{L}}$ and $K_{\mathrm{L}}$ (values of both characteristics below or above 1) to developing water deficit. $K_{\mathrm{L}}$ declined 2.3 times $(P<0.01)$ and $g_{\mathrm{L}}$ 1.4 times $(P<0.05)$ faster in humidity-treated trees compared to the control with decreasing $\Psi_{\mathrm{B}}$.

Mean values of the gas exchange and hydraulic characteristics for control (C treatment) and humidified trees are presented in Table 2. $E$ and $g_{\mathrm{L}}$ exhibited greater $(P<$ $0.05)$ values in $\mathbf{H}$ treatment both before branch cutting in the morning and under moderate water deficit $\left(\Psi_{\mathrm{L}} \geq-\right.$

Table 1 Results of ANCOVA for effects of the humidification treatment and fast-imposed water deficit on leaf water status, temperature, gas exchange and hydraulic conductance $(\mathrm{N}=117-124)$

\begin{tabular}{|c|c|c|c|}
\hline Dependent variable & Effect & Statistical significance & Partial $\eta^{2}$ \\
\hline \multirow[t]{2}{*}{ Leaf water potential, $\Psi_{\mathrm{L}}$} & Treatment & $P<0.001$ & 0.090 \\
\hline & Branch water status & $P<0.001$ & 0.763 \\
\hline \multirow[t]{2}{*}{ Leaf temperature, $T_{L}$} & Treatment & ns & - \\
\hline & Branch water status & $P<0.001$ & 0.246 \\
\hline \multirow[t]{2}{*}{ Leaf conductance to water vapour, $g \mathrm{~L}$} & Treatment & $P<0.001$ & 0.101 \\
\hline & Branch water status & $P<0.001$ & 0.544 \\
\hline \multirow[t]{3}{*}{ Transpiration rate, $E$} & Treatment & $P<0.001$ & 0.088 \\
\hline & Branch water status & $P<0.001$ & 0.401 \\
\hline & Leaf temperature & $P<0.001$ & 0.127 \\
\hline \multirow[t]{3}{*}{ Stomatal conductance, $g_{\mathrm{s}}$} & Treatment & $P=0.026$ & 0.041 \\
\hline & Branch water status & $P<0.001$ & 0.543 \\
\hline & Leaf temperature & $P=0.021$ & 0.044 \\
\hline \multirow[t]{2}{*}{ Ratio of intercellular to ambient $\mathrm{CO}_{2}$ concentrations, $C_{i} / C_{a}$} & Treatment & ns & - \\
\hline & Branch water status & $P<0.001$ & 0.338 \\
\hline \multirow[t]{3}{*}{ Net photosynthesis, $A_{n}$} & Treatment & ns & - \\
\hline & Branch water status & $P<0.001$ & 0.518 \\
\hline & Leaf temperature & $P=0.039$ & 0.037 \\
\hline \multirow[t]{2}{*}{ Intrinsic water-use efficiency, IWUE } & Treatment & ns & - \\
\hline & Branch water status & $P<0.001$ & 0.140 \\
\hline \multirow[t]{3}{*}{ Leaf hydraulic conductance, $K_{\mathrm{L}}$} & Treatment & $P=0.022$ & 0.039 \\
\hline & Leaf water status & $P<0.001$ & 0.433 \\
\hline & Leaf temperature & $P=0.004$ & 0.062 \\
\hline
\end{tabular}



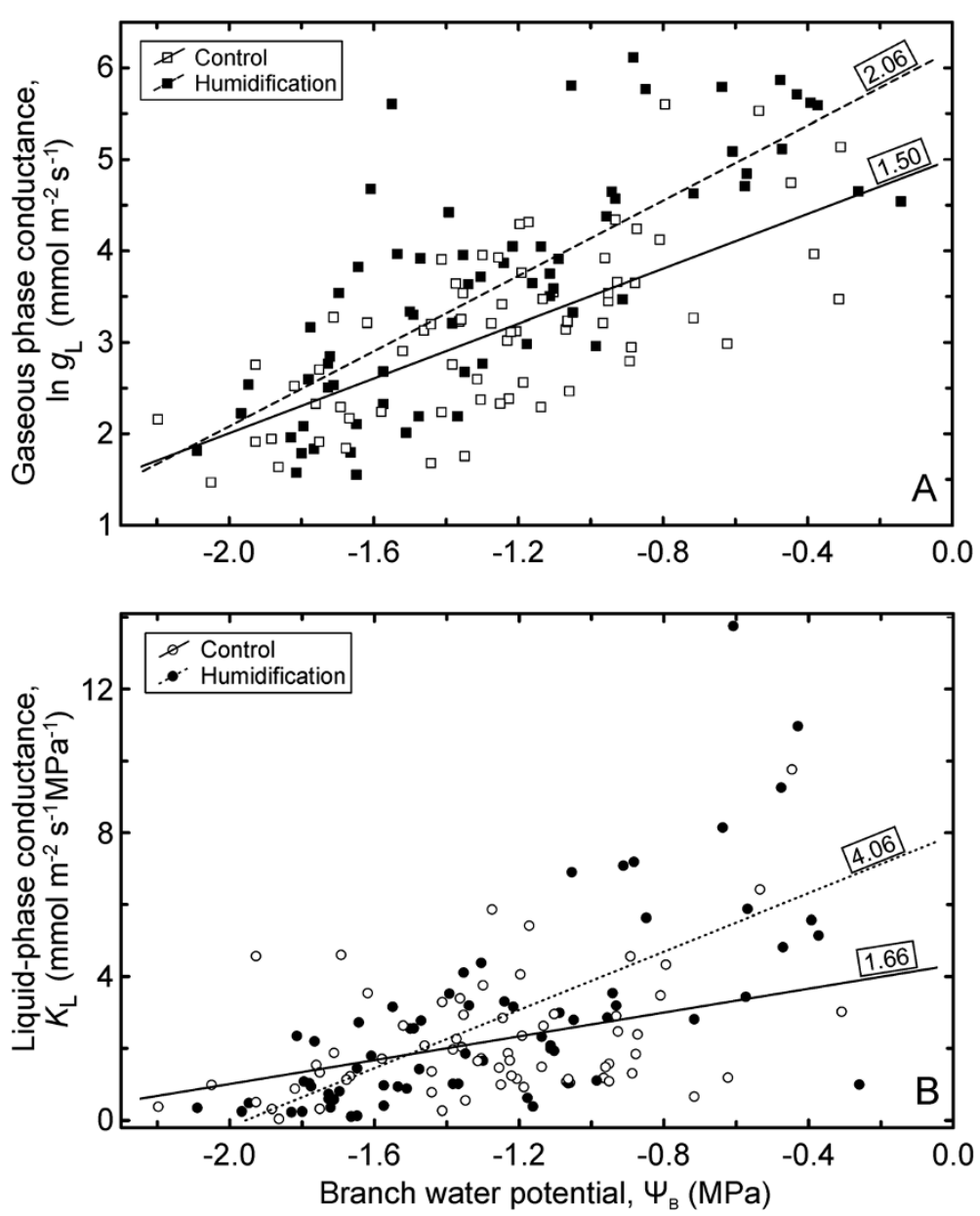

Figure 2 Branch water potential $\left(\Psi_{\mathrm{B}}\right)$ versus leaf conductance to water vapour $\left(g_{\mathrm{L}} ; \mathrm{A}\right)$ and leaf hydraulic conductance $\left(K_{\mathrm{L}} ; \mathrm{B}\right)$ in control and humidified trees. The numbers by the regression lines indicate the respective slopes.

1.55 $\mathrm{MPa})$. Under moderate water deficit, $T_{\mathrm{L}}$ was less and $K_{\mathrm{L}}$ greater in $\mathbf{H}$ than in $\mathbf{C}$ branches $(P<0.05)$. The means of other gas exchange parameters showed no difference among treatments. Water deficit developed rapidly after branch cutting, thereby leading to a decline in most parameters, including $K_{\mathrm{L}}$.

Net photosynthetic rates were strongly correlated with stomatal conductance $\left(g_{S} ; \mathrm{R}^{2}=0.970, P<0.001\right)$ across a wide range of stomatal openness for both treatments combined (Figure 3A). At first IWUE increased in response to the rapidly-induced water deficit and attained a maximum of $>70 \mu \mathrm{mol} \mathrm{mol}{ }^{-1}$, corresponding to $g_{\mathrm{S}} \sim 0.06 \mathrm{~mol} \mathrm{~m}^{-2} \mathrm{~s}^{-1}$ (Figure $3 \mathrm{~B}$ ). When $g_{\mathrm{S}}$ fell below this value (at $\Psi_{\mathrm{B}}<-1.0 \mathrm{MPa}$ ), IWUE declined very steeply as $A_{\mathrm{n}}$ decreased more rapidly than $g_{\mathrm{S}}$. Two characteristics $-T_{\mathrm{L}}$ and $C_{\mathrm{i}} / C_{\mathrm{a}}-$ demonstrated opposite trends with increasing water deficit. None of the characteristics differed significantly among the treatments under severe water deficit $\left(\Psi_{\mathrm{L}}<-1.55 \mathrm{MPa}\right.$; Table 2).

\section{Long-term effects of water deficit}

Long-term water deficit was imposed by reducing soil water availability due to a moderate drought that developed in July (Table 3; Figure 4). Although the misting application decreased transpirational water loss, bulk soil water potential $\left(\Psi_{\mathrm{S}}\right)$ in $\mathbf{H}$ plots also underwent substantial decline (dropped to $-180 \mathrm{kPa}$ ) in July. Inclusion of $\Psi_{\mathrm{S}}$ as an index of soil water availability into the analysis models changed the outcome radically: the effect of the humidification treatment became - with one exception - insignificant for all gas exchange and water relations characteristics (Table 4). Only $g_{\mathrm{L}}$ depended simultaneously on the treatment $(P=$ 0.036), rapidly-induced water deficit $\left(\Psi_{\mathrm{B}} ; P<0.001\right)$ as well as soil water availability $\left(\Psi_{S} ; P<0.001\right)$. Consequently, the effects of humidification manipulation were to a great extent realized through changes in soil water status. Four characteristics $\left[g_{\mathrm{L}}, E\right.$, soil-to-branch hydraulic conductance $\left(K_{\mathrm{S}-\mathrm{B}}\right)$ and whole-tree hydraulic conductance $\left(K_{\mathrm{T}}\right)$ ] were $2.1-2.3$ times greater in humidified trees than in control trees. 
Table 2 Comparison of mean values of physiological characteristics in control $(\mathrm{C})$ and humidified trees $(\mathrm{H})$ before branch cutting (on intact trees) and depending on severity of water deficit $\left(\Psi_{\mathrm{L}}<-1.55 \mathrm{MPa}\right.$ versus $\left.\Psi_{\mathrm{L}} \geq-1.55 \mathrm{MPa}\right)$

\begin{tabular}{|c|c|c|c|c|c|c|}
\hline \multirow{2}{*}{ Characteristic } & \multicolumn{2}{|c|}{ Before cutting } & \multicolumn{2}{|c|}{$\Psi_{\mathrm{L}} \geq-1.55 \mathrm{MPa}$} & \multicolumn{2}{|c|}{$\Psi_{\mathrm{L}}<-1.55 \mathrm{MPa}$} \\
\hline & $\mathrm{C}$ & $\mathbf{H}$ & $\mathrm{C}$ & $\mathbf{H}$ & $\mathrm{C}$ & $\mathrm{H}$ \\
\hline$\Psi_{\mathrm{L}}(\mathrm{MPa})$ & -1.07 & -1.03 & -1.26 & -1.25 & -1.91 & -2.10 \\
\hline$\Psi_{\mathrm{B}}(\mathrm{MPa})$ & -0.81 & -0.65 & -0.98 & -0.90 & -1.62 & -1.56 \\
\hline$T_{\mathrm{L}}\left({ }^{\circ} \mathrm{C}\right)$ & 26.2 & 25.4 & $27.6^{*}$ & $26.2^{*}$ & 28.8 & 29.3 \\
\hline$g_{L}\left(\mathrm{~mol} \mathrm{~m} \mathrm{~m}^{-2} \mathrm{~s}^{-1}\right)$ & $0.071^{*}$ & $0.166^{*}$ & $0.044^{* *}$ & $0.101^{* *}$ & 0.026 & 0.060 \\
\hline$E\left(\mathrm{mmol} \mathrm{m}{ }^{-2} \mathrm{~s}^{-1}\right)$ & $0.92^{*}$ & $2.07^{*}$ & $0.65^{* *}$ & $1.33^{* *}$ & 0.47 & 1.00 \\
\hline$g_{s}\left(\mathrm{~mol} \mathrm{~m}{ }^{-2} \mathrm{~s}^{-1}\right)$ & 0.145 & 0.237 & 0.086 & 0.138 & 0.046 & 0.060 \\
\hline$C_{\mathrm{i}} / C_{\mathrm{a}}$ (dimensionless) & 0.70 & 0.68 & 0.74 & 0.71 & 0.87 & 0.89 \\
\hline$A_{n}\left(\mu \mathrm{mol} \mathrm{m} \mathrm{m}^{-2} \mathrm{~s}^{-1}\right)$ & 6.47 & 9.29 & 4.21 & 5.96 & 2.00 & 2.66 \\
\hline IWUE $\left(\mu \mathrm{mol} \mathrm{mol}^{-1}\right)$ & 51.3 & 48.2 & 49.3 & 49.9 & 35.3 & 32.8 \\
\hline$K_{\mathrm{L}^{\prime}}\left(\mathrm{mmol} \mathrm{m} \mathrm{m}^{-2} \mathrm{~s}^{-1} \mathrm{MPa}^{-1}\right)$ & 3.65 & 5.88 & $2.47^{*}$ & $3.78^{*}$ & 1.85 & 1.88 \\
\hline$R_{\mathrm{L}}$ (dimensionless) & 0.32 & 0.44 & - & - & - & - \\
\hline$K_{\mathrm{S}-\mathrm{B}}\left(\mathrm{mmol} \mathrm{m} \mathrm{m}^{-2} \mathrm{~s}^{-1} \mathrm{MPa}^{-1}\right)$ & $2.28^{*}$ & $5.26^{*}$ & - & - & - & - \\
\hline$K_{T}\left(\mathrm{mmol} \mathrm{m}^{-2} \mathrm{~s}^{-1} \mathrm{MPa}^{-1}\right)$ & $1.15^{*}$ & $2.36^{*}$ & - & - & - & - \\
\hline
\end{tabular}

$\Psi_{\mathrm{L}}$, leaf water potential; $\Psi_{\mathrm{B}}$, branch water potential; $T_{\mathrm{L}}$, leaf temperature; $g_{\mathrm{L}}$, leaf conductance to water vapour; $E$, transpiration rate; $g_{\mathrm{S}}$, stomatal conductance to water vapour; $C_{\mathrm{i}} / C_{\mathrm{a}}$, ratio of intercellular to ambient $\mathrm{CO}_{2}$ concentrations; $A_{\mathrm{n}}$, net photosynthesis; IWUE, intrinsic water-use efficiency; $K_{\mathrm{L}}$, leaf hydraulic conductance; $R_{\mathrm{L}}$, relative leaf hydraulic resistance; $K_{\mathrm{S}-\mathrm{B}}$, soil-to-branch hydraulic conductance; $K_{\mathrm{T}}$, whole-tree hydraulic conductance. Statistical significance of the difference: ${ }^{*} P<0.05,{ }^{* *} P<0.01$

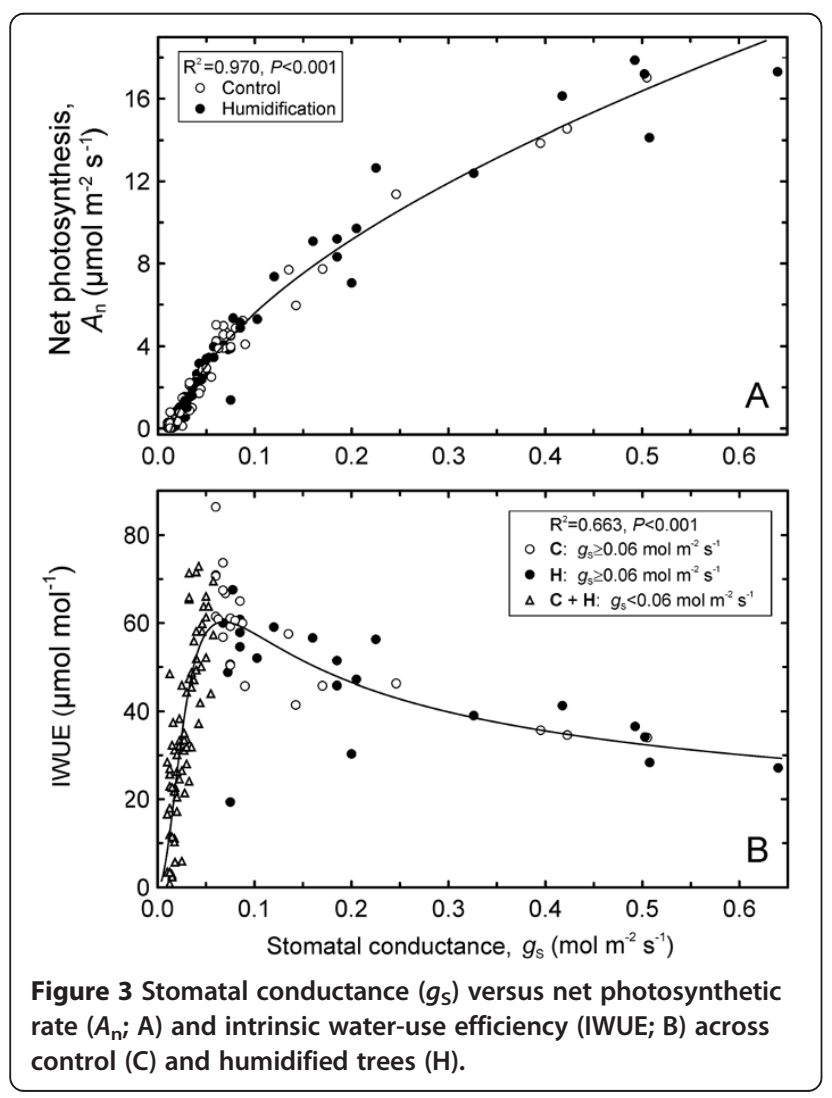

In fact, the differences in physiological characteristics between the treatments recorded on intact branches in the morning (Table 2) reflect co-effects of the air humidification and long-term soil water deficit. The responses of $g_{\mathrm{L}}$ and $K_{\mathrm{L}}$ to variation in $\Psi_{\mathrm{B}}$ were analysed also separately for the data obtained before and after cutting branches, and for moister $\left(\Psi_{\mathrm{S}}>-218 \mathrm{kPa}\right)$ and drier soil conditions $\left(\Psi_{\mathrm{S}} \leq-218\right.$ $\mathrm{kPa})$. Before cutting, neither of the response slopes differed between the treatments; after cutting, both slopes differed significantly between the treatments $\left(g_{\mathrm{L}}, P<0.05 ; K_{\mathrm{L}}, P<\right.$ 0.01). $\mathrm{d} g_{\mathrm{L}} / \mathrm{d} \Psi_{\mathrm{B}}$ and $\mathrm{d} K_{\mathrm{L}} / \mathrm{d} \Psi_{\mathrm{B}}$ showed no difference within treatments between the different soil moisture ranges.

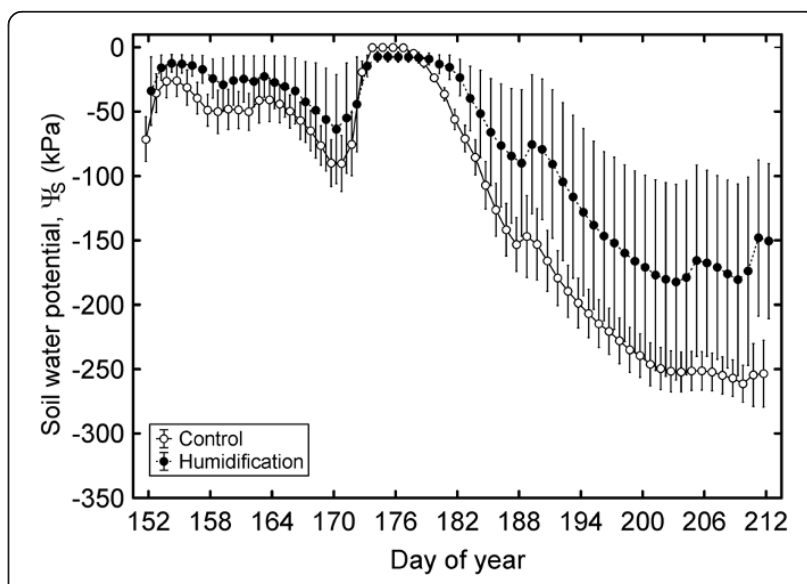

Figure 4 Mean bulk soil water potential $\left(\Psi_{S}\right)$ in control and humidified plots in June and July 2010. The error bars denote S.E. 
Table 3 Sums of precipitation $(\mathrm{mm})$ at the FAHM site in June and July

\begin{tabular}{lccc}
\hline \multirow{2}{*}{ Month } & \multicolumn{3}{c}{ Year } \\
\cline { 2 - 4 } & $\mathbf{2 0 0 8}$ & $\mathbf{2 0 0 9}$ & $\mathbf{2 0 1 0}$ \\
\hline June & 79 & 152 & 110 \\
July & 64 & 90 & 33 \\
\hline
\end{tabular}

\section{Liquid versus gaseous phase conductance}

Changes in $K_{\mathrm{L}}$ were co-ordinated with those in both stomatal conductance and net photosynthesis, while the relationships were substantially stronger for humidified trees. Specifically, $\mathrm{R}^{2}$ in $\mathrm{C}$ treatment was 0.264 and 0.293 for $g_{\mathrm{S}}$ and $A_{\mathrm{n}}$, respectively. In $\mathbf{H}$ treatment the respective $\mathrm{R}^{2}$ values were 0.583 and 0.601 (for all cases $P<0.001$ ). $g_{\mathrm{S}}$ and $A_{\mathrm{n}}$ were associated considerably more strongly with $K_{\mathrm{S}-\mathrm{B}}$ $\left(\mathrm{R}^{2}=0.75-0.85\right)$ and $K_{\mathrm{T}}\left(\mathrm{R}^{2}=0.80-0.85\right.$; Figure 5). IWUE in intact branches declined with increasing hydraulic capacity: with $K_{\mathrm{L}}\left(\mathrm{R}^{2}=0.204, P<0.05\right), K_{\mathrm{S}-\mathrm{B}}\left(\mathrm{R}^{2}=0.356, P<0.01\right)$ as well as $K_{\mathrm{T}}\left(\mathrm{R}^{2}=0.356, P<0.01\right)$. There was no statistical relationship between $K_{\mathrm{L}}$ and IWUE across the whole data sets (i.e., throughout the whole range of water deficit). The reliability of gasometric measurements was proved by an excellent accord among the readings obtained with different instruments: although $g_{\mathrm{S}}$ and total leaf conductance $\left(g_{\mathrm{L}}\right)$ were measured on different leaves and under different

Table 4 Results of ANCOVA for effects of the humidification treatment and fast and long-term water deficit on leaf water status, temperature, gas exchange and hydraulic conductance $(\mathrm{N}=117-124)$

\begin{tabular}{|c|c|c|c|}
\hline Dependent variable & Effect & Statistical significance & Partial $\eta^{2}$ \\
\hline \multirow[t]{3}{*}{ Leaf water potential, $\Psi_{L}$} & Treatment & ns & - \\
\hline & Branch water status & $P<0.001$ & 0.808 \\
\hline & Soil water availability & $P<0.001$ & 0.209 \\
\hline \multirow[t]{3}{*}{ Leaf temperature, $T_{L}$} & Treatment & ns & - \\
\hline & Branch water status & $P<0.001$ & 0.246 \\
\hline & Soil water availability & ns & - \\
\hline \multirow[t]{3}{*}{ Leaf conductance to water vapour, $g \mathrm{~L}$} & Treatment & $P=0.036$ & 0.033 \\
\hline & Branch water status & $P<0.001$ & 0.572 \\
\hline & Soil water availability & $P<0.001$ & 0.164 \\
\hline \multirow[t]{4}{*}{ Transpiration rate, $E$} & Treatment & ns & - \\
\hline & Branch water status & $P<0.001$ & 0.413 \\
\hline & Soil water availability & $P<0.001$ & 0.145 \\
\hline & Leaf temperature & $P<0.001$ & 0.129 \\
\hline \multirow[t]{4}{*}{ Stomatal conductance, $g_{\mathrm{s}}$} & Treatment & ns & - \\
\hline & Branch water status & $P<0.001$ & 0.560 \\
\hline & Soil water availability & $P<0.001$ & 0.184 \\
\hline & Leaf temperature & $P=0.001$ & 0.087 \\
\hline \multirow[t]{3}{*}{ Ratio of intercellular to ambient $\mathrm{CO}_{2}$ concentrations, $C_{i} / C_{a}$} & Treatment & ns & - \\
\hline & Branch water status & $P<0.001$ & 0.338 \\
\hline & Soil water availability & ns & - \\
\hline \multirow[t]{4}{*}{ Net photosynthesis, $A_{n}$} & Treatment & ns & - \\
\hline & Branch water status & $P<0.001$ & 0.526 \\
\hline & Soil water availability & $P<0.001$ & 0.122 \\
\hline & Leaf temperature & $P=0.006$ & 0.067 \\
\hline \multirow[t]{3}{*}{ Intrinsic water-use efficiency, IWUE } & Treatment & ns & - \\
\hline & Branch water status & $P<0.001$ & 0.140 \\
\hline & Soil water availability & ns & - \\
\hline \multirow[t]{4}{*}{ Leaf hydraulic conductance, $K_{\mathrm{L}}$} & Treatment & ns & - \\
\hline & Leaf water status & $P<0.001$ & 0.465 \\
\hline & Soil water availability & $P=0.003$ & 0.064 \\
\hline & Leaf temperature & $P=0.002$ & 0.073 \\
\hline
\end{tabular}

ns, not significant. 


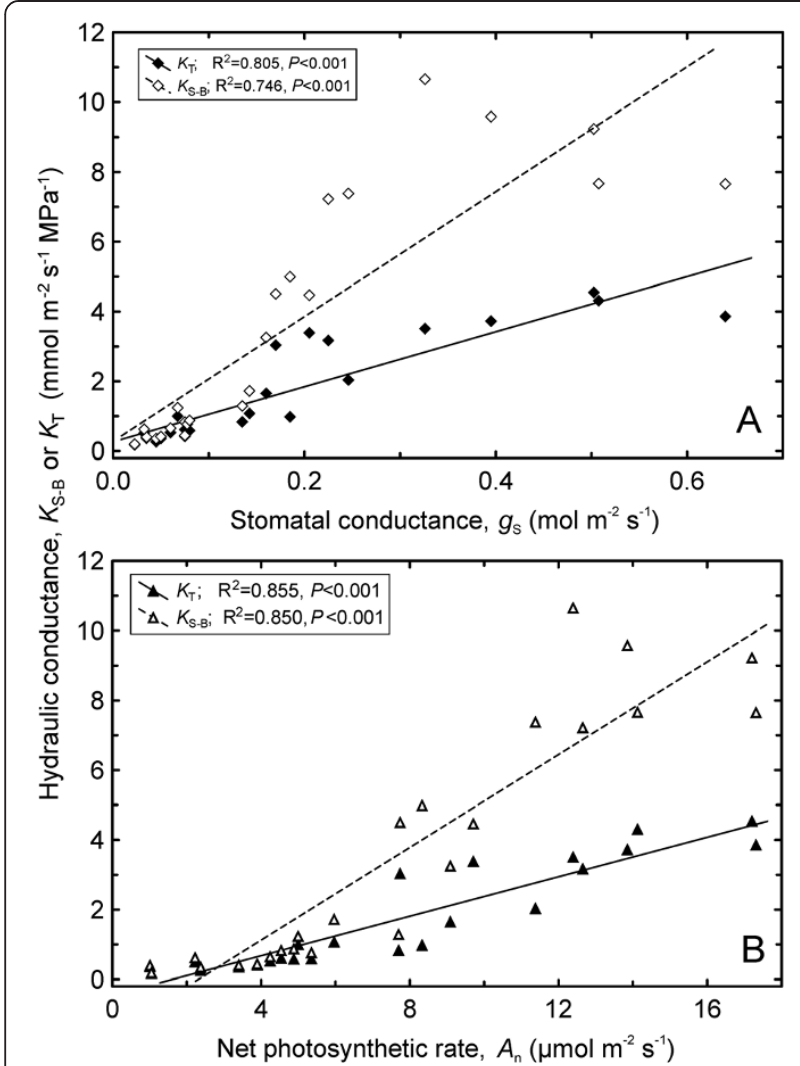

Figure 5 Co-ordination between gaseous and liquid-phase conductances. Stomatal conductance to water vapour $\left(g_{s} ; \mathbf{A}\right)$ and net photosynthetic rate $\left(A_{n} ; \mathbf{B}\right)$ versus soil-to-branch hydraulic conductance $\left(K_{\mathrm{S}-\mathrm{B}}\right)$ and whole-tree conductance $\left(K_{\mathrm{T}}\right)$ across humidification and control treatments.

conditions (controlled versus ambient conditions, respectively), the two characteristics exhibited a near perfect concordance $\left(\mathbf{R}^{2}=0.944\right.$ for $\mathbf{C}$ trees, $\mathbf{R}^{2}=0.901$ for $\mathbf{H}$ trees, for both $P<0.001$ ).

\section{Discussion}

\section{General responses to water deficit}

The rapidly-induced water deficit had highly significant $(P<0.001)$ effect on all parameters measured at the leaf level (Table 1). Under moderate water deficit $\left(\Psi_{\mathrm{L}} \geq-\right.$ $1.55 \mathrm{MPa}$ ) leaf conductance to water vapour, transpiration rate and leaf hydraulic conductance were significantly $(P$ $<0.05)$ higher in trees grown at elevated air humidity than in control trees. These differences are attributable to higher initial values (a result of long-term effects) and probably also to larger branch internal water storage in $\mathbf{H}$ treatment under moderate drought, although statistically not proven by the $\Psi_{\mathrm{B}}$ data. Leaf temperature, on the contrary, was higher $(P<0.05)$ in $\mathbf{C}$ trees due to the diminished transpiration. Under severe water deficit $\left(\Psi_{\mathrm{L}}<-1.55 \mathrm{MPa}\right)$ the treatments showed no difference in any of the characteristics (Table 2).
Two characteristics $-g_{\mathrm{L}}$ and $K_{\mathrm{L}}-$ exhibited a significantly steeper decline with increasing water deficit in $\mathbf{H}$ treatment than in the control, indicating higher susceptibility to weather fluctuations of trees grown under increased $\mathrm{RH}$. The observed stomatal responses are primarily associated with impact of rapidly-induced water deficit and obviously driven by hydraulic signals, because $\mathrm{d} g_{\mathrm{L}} / \mathrm{d} \Psi_{\mathrm{B}}$ did not differ between the treatments in intact branches and did not depend on soil water status if the data was analysed separately in subsets. Thus, the effect of soil drying is secondary. Various mechanisms are suggested as signalling cues to initiate or enhance ABA biosynthesis, including hydraulic signals [36]. The priority of hydraulic versus metabolic stimuli is considered fundamentally important in preventing plant desiccation and is maintained in stomatal control through vascular plant phylogeny [37,38]. However, the apparent change in stomatal sensitivity to branch water status induced by the humidity manipulation could be due to differences in the leaf-borne ABA levels, as previous reports describe that endogenous $\mathrm{ABA}$ concentrations in leaves grown for a long time under high humidity are lower than under moderate humidity $[11,12]$. Also fast de novo synthesis or conversion of inactive conjugates of ABA $[15,16]$ in shoot vascular tissues triggered by branch dehydration cannot be dismissed. Although studies on Arabidopsis thaliana provide crucial information on stomatal responses, species-specific differences exist, especially when the plants are exposed to simultaneously changing environmental factors [39].

Thus, our experiment supports the first hypothesis that trees acclimated to higher humidity exhibit greater sensitivity to rapidly-induced water deficit with respect to two functional traits. However, these changes have different consequences on plant water status. The reduction of $g_{\mathrm{L}}$ helps to limit water loss, slows down further $\Psi_{\mathrm{L}}$ falling and prevents runaway xylem embolism. The impact of decreasing $K_{\mathrm{L}}$ is opposite - leaf water supply declines causing $\Psi_{\mathrm{L}}$ to fall. Birch trees showed differential changes in these two fundamental traits due to the experimental manipulation: the humidity-treated trees exhibited substantially faster water deficit-driven reduction in $K_{\mathrm{L}}$ than in $g_{\mathrm{L}}$ if compared to the control. Thus, greater risk of leaf dehydration and xylem dysfunction is probably imposed on the trees grown under higher atmospheric humidity in case of sudden weather extremes, because strict stomatal control over water loss is a crucial factor in preventing water deficit-induced xylem cavitation [13]. Plant hydraulic conductance does not limit stomatal openness under moist weather conditions, but it could become crucial in climate extremes (severe drought, disastrous heat wave), which are scarcely predictable and yet will become more frequent in the future [8]. Among ecosystems, forests are particularly sensitive to climate change, because the long life-span and conservative 
structure of the water-conducting system of trees do not allow rapid acclimation to environmental fluctuations [3].

The air humidification manipulation affected most of the studied characteristics, but not IWUE (Table 1), unlike the soil humidity manipulation reported by Possen et al. [40]. In some species even long-term soil drought does not affect IWUE if $A_{\mathrm{n}}$ and $g_{\mathrm{S}}$ decrease with equal rates [41]. The inclusion of $\Psi_{\mathrm{S}}$ in the analysis models excluded the treatment effect (Table 4), suggesting that the impact of experimental manipulation in droughty summer (Table 3 ) is realized largely through changes in soil water status (i.e. due to higher $\Psi_{\mathrm{S}}$ in $\mathbf{H}$ treatment). Only leaf conductance to water vapour $\left(g_{\mathrm{L}}\right)$ depended simultaneously on the treatment $(P=0.036)$, rapidly-induced water deficit $(P<0.001)$ and soil water availability $(P<0.001)$. However, $g_{\mathrm{L}}$ in $\mathbf{H}$ trees demonstrated higher sensitivity to water deficit, i.e. an opposite trend to that observed by Fanourakis et al. [4]. Weak stomatal control could be a consequence of the low transpiration in plants grown continuously under high $\mathrm{RH}$ $(>85 \%)$. The degree of stomatal acclimation depends on both the duration and timing of exposure to high $\mathrm{RH}$ during leaf development, while determinative is just a stage of leaf expansion completion [4]. In silver birch, elevated atmospheric humidity had the widest consequences on stomatal regulation, as the effects extended beyond that of soil water availability. This is an important point in view of climate change: Roelfsema and Hedrich [20] argue that stomata will play an essential role in the adaptation of plants to climate change, because of their interrelated roles in $\mathrm{CO}_{2}$ uptake and release of water. As for $g_{\mathrm{S}}$, we observed less pronounced response (compare Tables 1 and 4), obviously because of its being measured under artificial conditions (constant irradiance, temperature and air humidity).

\section{Changes in plant hydraulic traits}

The air humidity manipulation led to higher soil water availability (Figure 4) in $\mathbf{H}$ treatment due to reduced transpirational water loss [5,7] under low VPD during the misting application (Figure 1). This resulted in higher hydraulic capacity of the trees grown in more humid environment, i.e. a long-term effect (Table 2). This response was observed under the moderate drought in July 2010 (Table 3). By contrast, we did not observe unequivocal shifts in hydraulic traits in the rainy summer of 2009: $K_{\mathrm{L}}$ decreased, while hydraulic conductance of root systems $\left(K_{\mathrm{R}}\right)$ and leaf-specific conductivity of stem-wood increased in response to elevated RH [42]. The present study revealed some alleviating effect of elevated $\mathrm{RH}$ under moderate drought, and the plant response to increased air humidity seems to differ depending on prevailing weather conditions. Nor can we dismiss increased xylem vulnerability and possible hydraulic dysfunction under unexpected severe drought, although on average the climate will become more humid at high latitudes [2,3].
The differences in $K_{\mathrm{S}-\mathrm{B}}$ and $K_{\mathrm{T}}$ observed on intact trees in 2010 likely ensued from xylem cavitation in response to differential soil drying (i.e. a long-term effect) in the treatments. The differences in $K_{\mathrm{L}}$ resulted from rapidly-imposed water deficit rather than soil water availability, because $K_{\mathrm{L}}$ measured on intact branches showed no significant difference between the treatments (Table 2) and $\mathrm{d} K_{\mathrm{L}} / \mathrm{d} \Psi_{\mathrm{B}}$ was invariant of soil water status. $K_{\mathrm{S}-\mathrm{B}}$ demonstrated a greater intertreatment variation compared to $K_{\mathrm{L}}$ - by a factor of 2.3 versus 1.6 , respectively. This is attributable to greater susceptibility of root xylem than of shoot xylem to water stress-induced embolism [33,43]. Domec et al. [44] reported that $K_{\mathrm{R}}$ declines faster than $K_{\mathrm{L}}$ as soil dries. The increasing resistance between soil and trunk has been shown to be the main cause of $K_{\mathrm{T}}$ decline and has also the highest weight in the stomatal control [45]. We cannot exclude also concurrent mechanisms responsible for the differences in the decline of $K_{\mathrm{S}-\mathrm{B}}$ versus $K_{\mathrm{L}}$, such as that associated with contribution of apoplastic versus cellto-cell route to liquid water transport under water deficit. When transpiration stream is attenuated, plasma membrane AQPs are upregulated, the membrane water permeability increases and transcellular water flux becomes much more significant [46]. One must consider that the soil-to-branch pathway represents predominantly an apoplastic route, while in leaves the contributions of the two routes to the total hydraulic resistance are of the same magnitude [47]. Nevertheless, Johnson et al. [48,49] measured $K_{\mathrm{L}}$ concurrently with ultrasonic acoustic emissions in dehydrating leaves of several woody species and presented reliable evidence that xylem embolism is a primary factor in dehydration-induced declines in leaf hydraulic conductance. Findings of Nardini et al. [50] highlight the role of regulation of $K_{\mathrm{L}}$ in plant acclimation suggesting that leaf resistance to drought-induced hydraulic dysfunction is a key to plant survival and competition even over limited geographical ranges.

\section{Co-ordination between gas exchange and hydraulic traits}

Net photosynthetic rate $\left(A_{\mathrm{n}}\right)$ and stomatal conductance $\left(g_{\mathrm{S}}\right)$ in silver birch were positively correlated with plant hydraulic characteristics (Figure 5), whereas gas exchange parameters were considerably more strongly associated with $K_{\mathrm{S}-\mathrm{B}}$ or $K_{\mathrm{T}}$ than with $K_{\mathrm{L}}$. This result confirms that maximum $g_{\mathrm{S}}$ and $A_{\mathrm{n}}$ depend on hydraulic conductance of the whole soil-to-leaf pathway (expresses potential capability for leaf water supply) rather than solely on that of the leaf $[45,51,52]$.

The rapidly-imposed water deficit affected $(P<0.001)$ all parameters measured at the leaf level, showing substantially stronger association with $\Psi_{\mathrm{B}}$ than with $\Psi_{\mathrm{L}}$ (Table 1). Thus, the gas exchange and stomatal conductance of silver birch are determined by direct water availability to the leaf, estimated by $\Psi_{\mathrm{B}}$ in the petiole insertion point, rather than by 
the current leaf water status $\left(\Psi_{\mathrm{L}}\right)$ itself. The relationship between gas exchange and $\Psi_{\mathrm{B}}$ is probably mediated by stem hydraulic capacitance, because the internal water storage in trees plays a role in mitigating diurnal fluctuations in plant water status caused by transpirational water losses $[14,53]$. So, plants with a great capacity to avoid high stem water deficits during periods of high transpiration tend to have a relatively risky stomatal strategy and maintain higher midday $g_{\mathrm{S}}$ [17]. On the other hand, our results support the idea that stomatal openness is regulated in a way to prevent primarily dysfunction of stem xylem, as proposed by Meinzer et al. [14]. This is likely a general trait for broad-leaved trees, as recently reported for a number of subtropical tree species [17].

Leaf gaseous phase conductance began to decrease simultaneously with $K_{\mathrm{L}}$ in response to the rapidly-imposed water deficit, i.e. with no threshold level in the water potential range experienced in the present study. This result coincides with that obtained on leaves of Quercus, Pinus and Pseudotsuga species [54]. Although the field measurements under uncontrolled conditions did not allow construction of vulnerability curves, our data imply narrow hydraulic safety margin existing in silver birch (the $50 \%$ decline of $K_{\mathrm{L}}$ was observed at about $-1.2 \mathrm{MPa}$ ), a characteristic of angiosperm species [55]. Blackman et al. [56] sampled 20 phylogenetically disparate woody angiosperms and found that the greater the water potential inducing a $50 \%$ loss in $K_{\mathrm{L}}$, the narrower the safety margin. This trait suits well with general life strategy of a fast-growing pioneer species, such as $B$. pendula. In this context the present result is consistent with our previous findings: stomatal sensitivity of sun leaves of B. pendula to atmospheric VPD $\left(80 \mathrm{mmol} \mathrm{m}^{-2} \mathrm{~s}^{-1}\right.$ $\left.\ln (\mathrm{kPa})^{-1}[57]\right)$ exceeds the corresponding mean of angiosperms $\left(73 \mathrm{mmol} \mathrm{m}{ }^{-2} \mathrm{~s}^{-1} \ln (\mathrm{kPa})^{-1}\right.$ [55]). Contrary to the paradigm that isohydric species avoid cavitation, it has been revealed that relatively isohydric species tend to experience far greater cavitation and refilling of xylem on a daily basis than anisohydric species, the benefit of which is enhanced capacitance for use in transpiration [58].

Silver birch has been reported to be able for efficient acclimation to lack of water, including adjustment of WUE [40]. Thus, the drought developed in Estonia in summer 2010 was not severe enough to induce significant changes in photosynthetic water-use efficiency (IWUE; Table 4). Our earlier studies $[57,59]$ performed on large birch trees growing in a natural forest stand revealed the opposing height-related trends in IWUE and soil-to-leaf hydraulic conductance $\left(K_{\mathrm{T}}\right)$ within tree crowns at sufficient light intensities, suggesting a trade-off between water transport and use efficiencies. The inverse relationships between hydraulic characteristics and IWUE found in this study suggest that the respective trade-off between hydraulic capacity and WUE occurs in silver birch both at the leaf $\left(K_{\mathrm{L}}\right)$ and whole-plant levels $\left(K_{\mathrm{T}}\right)$. The trade-off reflects co-ordinated adjustment of plant gas exchange and hydraulic system to long-term water deficit, but not a response to rapidly-imposed interference; therefore, the converse relation was discovered only in intact branches. Hence, it is always necessary to consider time scales when analysing trends in plant WUE. Abril and Hanano [19] indicated that WUE in Mediterranean woody species reduces during the day by water stress, but it increases as seasonal drought proceeds.

\section{Conclusions}

Our results support the hypothesis that physiological traits in trees acclimated to higher air humidity exhibit higher sensitivity to rapid water deficit with respect to two characteristics - leaf conductance to water vapour and leaf hydraulic conductance. Disproportionate changes in sensitivity of stomatal versus leaf hydraulic conductance to water deficit might impose greater risk of desiccationinduced hydraulic dysfunction on the plants, grown under high RH, in case of sudden weather fluctuations. We failed to discover a short-term trade-off between plant hydraulic capacity and photosynthetic water-use efficiency. The impact of air humidity manipulation was realized principally through changes in soil water availability, while the treatment may have different effects on plant functioning depending on weather conditions prevailing during the growing season.

\section{Methods}

\section{Study area and environmental variables}

The studies were carried out on 5-year-old silver birch (B. pendula) trees in an experimental forest plantation at the Free Air Humidity Manipulation (FAHM) site, situated in Rõka village $\left(58^{\circ} 14^{\prime} \mathrm{N}, 27^{\circ} 17^{\prime} \mathrm{E}, 40-48 \mathrm{~m} \mathrm{ASL}\right)$, Eastern Estonia, representing a hemiboreal vegetation zone. The long-term average annual precipitation in the region is $650 \mathrm{~mm}$ and the average temperature is $17.0^{\circ} \mathrm{C}$ in July and $-6.7^{\circ} \mathrm{C}$ in January. The growing season lasts 175 180 days from mid-April to October. The soil is a fertile Endogenic Mollic Planosol (WRB) with an A-horizon thickness of $27 \mathrm{~cm}$. Total nitrogen content is $0.11-0.14 \%, \mathrm{C} / \mathrm{N}$ ratio is 11.4 , and $\mathrm{pH}$ is $5.7-6.3$.

Three sample plots served as control areas ( $\mathbf{C}$ treatment) and three plots were humidified ( $\mathbf{H}$ treatment) using the computer-operated FAHM system. The system integrates two different technologies - a misting technique to atomize/vaporise water and a FACE-like technology to mix humidified air inside the plots, enabling relative humidity of the air $(\mathrm{RH})$ to be increased by up to $18 \%$ over the ambient level during humidification treatment, depending on the wind speed inside the experimental stand. The humidification was applied in daytime 6 days a week throughout the growing period if 
ambient RH was $<75 \%$ and mean wind speed $<4 \mathrm{~m} \mathrm{~s}^{-1}$. As a long-term average, $\mathrm{RH}$ was increased by $7-8 \%$. A detailed description of the FAHM site and technical setup has been presented by Kupper et al. [5]. The manipulation was started in June of 2008; gas exchange and hydraulic measurements were performed on $15 \mathbf{H}$ and $15 \mathrm{C}$ trees in June and July of 2010. Environmental variables measured continuously were air temperature $\left(T_{\mathrm{A}}\right)$ and relative humidity $(\mathrm{RH})$ with HMP45A humidity and temperature probes (Vaisala, Helsinki, Finland), precipitation with TR-4 tipping bucket rain gauges (Texas Electronics, Dallas, TX), bulk soil water potential $\left(\Psi_{\mathrm{S}}\right)$ with EQ2 equitensiometers (Delta-T Devices, Burwell, UK) at depths of 15 and $30 \mathrm{~cm}$. The readings of the sensors were stored as 10 minute average values with a DL2e data logger (Delta-T Devices).

\section{Gasometric and hydraulic measurements}

One sample branch (mean height above the ground $140 \pm 9.3 \mathrm{~cm}$ for $\mathbf{C}$ trees and $138 \pm 8.4 \mathrm{~cm}$ for $\mathbf{H}$ trees) per tree from the middle third of the crown was selected for gasometric and hydraulic measurements. Two branches, one from $\mathbf{C}$ and another form $\mathbf{H}$ treatment, were sampled simultaneously using two instruments. Net photosynthetic rate $\left(A_{\mathrm{n}}\right)$, stomatal conductance to water vapour $\left(g_{\mathrm{S}}\right)$ and ratio of intercellular to ambient $\mathrm{CO}_{2}$ concentrations $\left(C_{\mathrm{i}} / C_{\mathrm{a}}\right)$ were measured with a LCpro+ portable photosynthesis system (ADC BioScientific, Hoddesdon, UK) on four or five leaves per branch at a saturating photosynthetic photon flux density $\left(1196 \mu \mathrm{mol} \mathrm{m}{ }^{-2} \mathrm{~s}^{-1}\right)$ applying constant $\mathrm{CO}_{2}$ concentration $\left(C_{\mathrm{a}}=360 \mu \mathrm{mol} \mathrm{mol}^{-1}\right)$, air humidity (water vapour pressure $15 \mathrm{mbar}$ ) and temperature $\left(25^{\circ} \mathrm{C}\right)$. Leaf conductance to water vapour (i.e. total gaseous phase conductance, $g_{\mathrm{L}}$ ), transpiration rate $(E)$ and leaf temperature $\left(T_{\mathrm{L}}\right)$ were measured on six leaves per branch with a LI$1600 \mathrm{M}$ steady-state diffusion porometer (Li-Cor, Lincoln, $\mathrm{NE})$ at ambient conditions. Intrinsic water-use efficiency (IWUE) was calculated as the ratio of $A_{\mathrm{n}}$ to $g_{\mathrm{S}}[41,60]$. Bulk leaf water potential $\left(\Psi_{\mathrm{L}}\right)$ was determined in four detached leaves by the balancing pressure technique using a Scholander-type pressure chamber simultaneously with gas exchange measurements. Xylem water potential of the branches $\left(\Psi_{\mathrm{B}}\right)$ was estimated by applying the bagged leaves technique, sampling two leaves per branch at each measurement time, prepared the previous evening. Water potential of the non-transpiring (bagged) leaves, presumed to have equilibrated with the xylem water potential of the branch proximal to the petiole, was taken as an estimate of $\Psi_{\mathrm{B}}$. The first measurement series was performed on intact branches in the morning immediately before branch cutting. Then the sample branches were cut off and allowed to dehydrate in open-air conditions in order to generate a rapidly-imposed water deficit. The next four measurement series were conducted within $\sim 3 \mathrm{~h}$ after cutting. All measurements were done on dry leaves under non-misting conditions: on intact branches in the morning before misting started and after that outside the experimental plots.

Hydraulic conductance of leaves $\left(K_{\mathrm{L}}\right)$ was estimated by the evaporative flux method under steady-state conditions and was calculated according to the Ohm's law analogy:

$$
K_{\mathrm{L}}=\frac{E}{\Psi_{\mathrm{B}}-\Psi_{\mathrm{L}}},
$$

where $E$ is the evaporative flux. As $E$ is expressed per unit leaf area, values of $K_{\mathrm{L}}$ have been scaled by leaf area. $K_{\mathrm{L}}$ was standardized for the dynamic viscosity of water at $28^{\circ} \mathrm{C}$. Soil-to-branch $\left(K_{\mathrm{S}-\mathrm{B}}\right)$ and whole-tree hydraulic conductance $\left(K_{\mathrm{T}}\right)$ were calculated analogically based on water potential drops across the corresponding segments $\left(\Psi_{\mathrm{S}}-\Psi_{\mathrm{B}}\right.$ and $\Psi_{\mathrm{S}}-\Psi_{\mathrm{L}}$, respectively). $K_{\mathrm{S}-\mathrm{B}}$ and $K_{\mathrm{T}}$ were left unstandardized, because of variable temperature along these long transport pathways.

\section{Data analysis}

Statistical data analysis was carried out using Statistica, Vers. 7.1 (StatSoft Inc., Tulsa, OK). Effects of air humidification (treatment), rapidly-imposed (estimated by $\Psi_{\mathrm{L}}$ or $\Psi_{\mathrm{B}}$ ) and long-term water deficits (estimated by $\Psi_{\mathrm{S}}$ ) on leaf gas exchange and hydraulic conductance were analysed by applying analysis of covariance (ANCOVA). We acknowledge that data from such field experiments do not allow strict separation of the rapid and long-term effects of water deficit, however, this approach was encouraged by absence of differences both in $\Psi_{\mathrm{L}}$ and $\Psi_{\mathrm{B}}$ between the treatments before branch cutting in the morning (see Table 2). 'Treatment' was treated as a categorical predictor, while $\Psi_{\mathrm{S}}, T_{\mathrm{L}}$ and $\Psi_{\mathrm{L}}$ or $\Psi_{\mathrm{B}}$ were included in the analysis model as covariates; type IV sums of squares were used in the analysis. The ANCOVA was performed in two stages: first, analysis of the treatment and rapidly-imposed water deficit effects; second, addition of the effect of the longterm water deficit. Statistically insignificant covariates were removed from the final models. Effect sizes were assessed by partial eta-squared $\left(\eta_{\text {partial }}^{2}\right)$ defined as the ratio of variance accounted for by an effect and that effect plus its associated error variance [61]:

$$
\eta_{\text {partial }}^{2}=\frac{\mathrm{SS}_{\text {effect }}}{\mathrm{SS}_{\text {effect }}+\mathrm{SS}_{\text {error }}},
$$

where $\mathrm{SS}_{\text {effect }}$ is the sum of squares for given effect and $\mathrm{SS}_{\text {error }}$ is the sum of squares for the respective error term.

\section{Abbreviations}

Treatments: C: Control trees grown in natural air humidity; $\mathrm{H}$ : Trees grown in elevated air humidity; $A_{n}$ : Net photosynthetic rate; $A B A$ : Abscisic acid; AQP: Aquaporin; $C_{\mathrm{i}} / C_{\mathrm{a}}$ : Ratio of intercellular to ambient $\mathrm{CO}_{2}$ concentrations; $E$ : Transpiration rate; $g_{\mathrm{L}}$ : Leaf conductance to water vapour; $g_{\mathrm{S}}$ : Stomatal 
conductance; IWUE: Intrinsic water-use efficiency; $K_{\llcorner}$: Leaf hydraulic conductance; $K_{\mathrm{R}}$ : Root hydraulic conductance; $K_{\mathrm{S}-\mathrm{B}}$ : Soil-to-branch hydraulic conductance; $K_{\mathrm{T}}$ : Soil-to-leaf or whole-tree hydraulic conductance; $R_{\mathrm{L}}$ : Relative leaf hydraulic resistance; $\mathrm{RH}$ : Relative humidity of air; $T_{\mathrm{A}}$ : Air temperature; $T_{L}$ : Leaf temperature; VPD: Atmospheric water vapour pressure deficit; WUE: Water-use efficiency; $\Psi_{\mathrm{B}}$ : Branch water potential; $\psi_{\mathrm{L}}$ : Leaf water potential; $\psi_{\text {s: }}$ Bulk soil water potential.

\section{Competing interests}

The authors declare that they have no competing interests.

\section{Authors' contributions}

AS designed and performed the experiment, and wrote the manuscript. AN, EÕP and PK performed the experiment, analyzed the data and revised the paper. All authors read and approved the final manuscript.

\section{Acknowledgements}

This study was supported by the Estonian Science Foundation (Grant no. 8333), by the Estonian Ministry of Education and Research (target financing project SF0180025s12), and by the EU through the European Regional Development Fund (Centre of Excellence in Environmental Adaptation). We are grateful to Jaak Sõber for operating the FAHM humidification system and Robert Szava-Kovats for language revision.

Received: 30 December 2013 Accepted: 20 March 2014 Published: 24 March 2014

\section{References}

1. Climate Change, Impacts and Vulnerability in Europe 2012. An Indicator-Based Report. EEA Report No. 12/2012. Copenhagen: European Environment Agency; 2012.

2. Kont A, Jaagus J, Aunap R: Climate change scenarios and the effect of sea-level rise for Estonia. Glob Planet Change 2003, 36:1-15.

3. Lindner M, Maroschek M, Netherer S, Kremer A, Barbati A, Garcia-Gonzalo Seidl R, Delzon S, Corona P, Kolström M, Lexer MJ, Marchetti M: Climate change impacts, adaptive capacity, and vulnerability of European forest ecosystems. For Ecol Manage 2010, 259:698-709.

4. Fanourakis D, Carvalho SMP, Domingos PF, Almeida DPF, Heuvelink E: Avoiding high relative air humidity during critical stages of leaf ontogeny is decisive for stomatal functioning. Physiol Plant 2011, 142:274-286.

5. Kupper P, Sõber J, Sellin A, Lõhmus K, Tullus A, Räim O, Lubenets K, Tulva I, Uri V, Zobel M, Kull O, Sõber A: An experimental facility for Free Air Humidity Manipulation (FAHM) can alter water flux through deciduous tree canopy. Environ Exp Bot 2011, 72:432-438.

6. Cramer MD, Hawkins $\mathrm{H}-J$, Verboom GA: The importance of nutritional regulation of plant water flux. Oecologia 2009, 161:15-24.

7. Tullus A, Kupper P, Sellin A, Parts L, Sõber J, Tullus T, Lõhmus K, Sõber A, Tullus H: Climate change at northern latitudes: Rising atmospheric humidity decreases transpiration. $\mathrm{N}$-uptake and growth rate of hybrid aspen. PLOS One 2012, 7:e42648. doi:10.1371/journal.pone.0042648.

8. Easterling DR, Meehl GA, Parmesan C, Changnon SA, Karl TR, Mearns LO: Climate extremes: observations, modeling, and impacts. Science 2000, 289:2068-2074.

9. Granier A, Reichstein M, Bréda N, Janssens IA, Falge E, Ciais P, Grünwald T, Aubinet M, Berbigier P, Bernhofer C, Buchmann N, Facini O, Grassi G, Heinesch B, Ilvesniemi $H$, Keronen $P$, Knohl A, Köstner B, Lagergren F, Lindroth A, Longdoz B, Loustau D, Mateus J, Montagnani L, Nys C, Moors E, Papale D, Peiffer M, Pilegaard K, Pita G, et al: Evidence for soil water control on carbon and water dynamics in European forests during the extremely dry year: 2003. Agric For Meteorol 2007, 143:123-145.

10. Nardini A, Battistuzzo M, Savi T: Shoot desiccation and hydraulic failure in temperate woody angiosperms during an extreme summer drought. New Phytol 2013, 200:322-329.

11. Rezaei Nejad A, van Meeteren U: The role of abscisic acid in disturbed stomatal response characteristics of Tradescantia virginiana during growth at high relative air humidity. J Exp Bot 2007, 58:627-636.

12. Rezaei Nejad A, van Meeteren U: Dynamics of adaptation of stomatal behaviour to moderate or high relative air humidity in Tradescantia virginiana. J Exp Bot 2008, 59:289-301.
13. Sparks JP, Black RA: Regulation of water loss in populations of Populus trichocarpa: the role of stomatal control in preventing xylem cavitation. Tree Physiol 1999, 19:453-459.

14. Meinzer FC, Johnson DM, Lachenbruch B, McCulloh KA, Woodruff DR: Xylem hydraulic safety margins in woody plants: coordination of stomatal control of xylem tension with hydraulic capacitance. Funct Ecol 2009, 23:922-930.

15. Okamoto M, Tanaka Y, Abrams SR, Kamiya Y, Seki M, Nambara E: High humidity induces abscisic acid 8'-hydroxylase in stomata and vasculature to regulate local and systemic abscisic acid responses in Arabidopsis. Plant Physiol 2009, 149:825-834.

16. Kim T-H, Böhmer M, Hu H, Nishimura N, Schroeder Jl: Guard cell signal transduction network: advances in understanding abscisic acid, $\mathrm{CO}_{2}$, and $\mathrm{Ca}^{2+}$ signalling. Annu Rev Plant Biol 2010, 61:561-591.

17. Zhang Y-J, Meinzer FC, Qi J-H, Goldstein G, Cao K-F: Midday stomatal conductance is more related to stem rather than leaf water status in subtropical deciduous and evergreen broadleaf trees. Plant Cell Environ 2013, 36:149-158.

18. Davies WJ, Tardieu F, Trejo CL: How do chemical signals work in plants that grow in drying soil? Plant Physiol 1994, 104:309-314.

19. Abril M, Hanano R: Ecophysiological responses of three evergreen woody Mediterranean species to water stress. Acta Oecol 1998, 19:377-387.

20. Roelfsema MRG, Hedrich R: Stomata. In Encyclopedia of Life Sciences (ELS). Chichester: John Wiley \& Sons; 2009. doi:10.1002/9780470015902.a0002075.pub2.

21. Shatil-Cohen A, Attia Z, Moshelion M: Bundle-sheath cell regulation of xylem-mesophyll water transport via aquaporins under drought stress: a target of xylem-borne ABA? Plant J 2011, 67:72-80.

22. Comstock JP: Hydraulic and chemical signalling in the control of stomatal conductance and transpiration. J Exp Bot 2002, 53:195-200

23. de Miguel M, Sánchez-Gómez D, Cervera MT, Aranda I: Functional and genetic characterization of gas exchange and intrinsic water use efficiency in a full-sib family of Pinus pinaster Ait. in response to drought. Tree Physiol 2012, 32:94-103.

24. Aranda I, Alía R, Ortega U, Dantas ÂK, Majada J: Intra-specific variability in biomass partitioning and carbon isotopic discrimination under moderate drought stress in seedlings from four Pinus pinaster populations. Tree Genet Genom 2010, 6:169-178.

25. Christmann A, Hoffmann T, Teplova I, Grill E, Müller A: Generation of active pools of abscisic acid revealed by in vivo imaging of water-stressed Arabidopsis. Plant Physiol 2005, 137:209-219.

26. Bauer H, Ache P, Lautner S, Fromm J, Hartung W, Al-Rasheid KAS, Sonnewald S, Sonnewald U, Kneitz S, Lachmann N, Mendel RR, Bittner F, Hetherington AM, Hedrich R: The stomatal response to reduced relative humidity requires guard cell-autonomous ABA synthesis. Curr Biol 2013, 23:53-57.

27. Salleo S, Nardini A, Pitt F, Lo Gullo MA: Xylem cavitation and hydraulic control of stomatal conductance in laurel (Laurus nobilis L.). Plant Cell Environ 2000, 23:71-79.

28. Brodribb TJ, Holbrook NM: Changes in leaf hydraulic conductance during leaf shedding in seasonally dry tropical forest. New Phytol 2003, 158:295-303.

29. Brodribb TJ: Xylem hydraulic physiology: The functional backbone of terrestrial plant productivity. Plant Sci 2009, 177:245-251.

30. da Graça JP, Rodrigues FA, Farias JRB, Oliveira MCN, Hoffmann-Campo CB, Zingaretti SM: Physiological parameters in sugarcane cultivars submitted to water deficit. Braz J Plant Physiol 2010, 22:189-197.

31. Huang W, Fu P-L, Jiang YJ, Zhang $J$, Zhang S-B, Hu H, Cao K-F: Differences in the responses of photosystem I and photosystem II of three tree species Cleistanthus sumatranus, Celtis philippensis and Pistacia weinmannifolia exposed to a prolonged drought in a tropical limestone forest. Tree Physiol 2013, 33:211-220.

32. Tyree MT, Sperry JS: Vulnerability of xylem to cavitation and embolism. Annu Rev Plant Physiol Plant Mol Biol 1989, 40:19-38.

33. Domec J-C, Schäfer K, Oren R, Kim HS, McCarthy HR: Variable conductivity and embolism in roots and branches of four contrasting tree species and their impacts on whole-plant hydraulic performance under future atmospheric $\mathrm{CO}_{2}$ concentration. Tree Physiol 2010, 30:1001-1015.

34. Guyot G, Scoffoni C, Sack L: Combined impacts of irradiance and dehydration on leaf hydraulic conductance: insights into vulnerability and stomatal control. Plant Cell Environ 2012, 35:857-871.

35. Kaldenhoff R, Ribas-Carbo M, Flexas Sans J, Lovisolo C, Heckwolf M, Uehlein N: Aquaporins and plant water balance. Plant Cell Environ 2008, 31:658-666. 
36. Christmann A, Weiler EW, Steudle E, Grill E: A hydraulic signal in root-toshoot signalling of water shortage. Plant J 2007, 52:167-174.

37. Aasamaa K, Söber A: Responses of stomatal conductance to simultaneous changes in two environmental factors. Tree Physiol 2011, 31:855-864.

38. Brodribb TJ, McAdam SAM: Stomatal (mis)behaviour. Tree Physiol 2011, 31:1039-1040.

39. Merilo E, Jõesaar I, Brosché M, Kollist H: To open or to close: speciesspecific stomatal responses to simultaneously applied opposing environmental factors. New Phytol 2014, 202:499-508.

40. Possen BJHM, Oksanen E, Rousi M, Ruhanen $H$, Ahonen V, Tervahauta A, Heinonen J, Heiskanen J, Kärenlampi S, Vapaavuori E: Adaptability of birch (Betula pendula Roth) and aspen (Populus tremula L.) genotypes to different soil moisture conditions. Forest Ecol Manage 2011, 262:1387-1399.

41. Letts MG, Johnson DRE, Coburn CA: Drought stress ecophysiology of shrub and grass functional groups on opposing slope aspects of a temperate grassland valley. Botany 2010, 88:850-866.

42. Sellin A, Tullus A, Niglas A, Õunapuu E, Karusion A, Lõhmus K: Humiditydriven changes in growth rate, photosynthetic capacity, hydraulic properties and other functional traits in silver birch (Betula pendula). Ecol Res 2013, 28:523-535.

43. Domec J-C, Warren J, Lachenbruch B, Meinzer FC: Safety factors from air seeding and cell wall implosion in young and old conifer trees. IAWA J 2009, 30:100-120.

44. Domec J-C, Noormets A, King JS, Sun G, Mcnulty SG, Gavazzi MJ, Boggs JL, Treasure EA: Decoupling the influence of leaf and root hydraulic conductances on stomatal conductance and its sensitivity to vapour pressure deficit as soil dries in a drained loblolly pine plantation. Plant Cell Environ 2009, 32:980-991.

45. Aranda I, Gil L, Pardos JA: Seasonal changes in apparent hydraulic conductance and their implications for water use of European beech (Fagus sylvatica L.) and sessile oak [Quercus petraea (Matt.) Liebl] in South Europe. Plant Ecol 2005, 179:155-167

46. Morillon R, Chrispeels MJ: The role of $A B A$ and the transpiration stream in the regulation of the osmotic water permeability of leaf cells. Proc Natl Acad Sci USA 2001, 98:14138-14143.

47. Sack L, Holbrook NM: Leaf hydraulics. Annu Rev Plant Biol 2006, 57:361-381.

48. Johnson DM, Meinzer FC, Woodruff DR, McCulloh KA: Leaf xylem embolism, detected acoustically and by cryo-SEM, corresponds to decreases in leaf hydraulic conductance in four evergreen species. Plant Cell Environ 2009, 32:828-836.

49. Johnson DM, McCulloh KA, Woodruff DR, Meinzer FC: Evidence for xylem embolism as a primary factor in dehydration-induced declines in leaf hydraulic conductance. Plant Cell Environ 2012, 35:760-769.

50. Nardini A, Pedà G, La Rocca N: Trade-offs between leaf hydraulic capacity and drought vulnerability: morpho-anatomical bases, carbon costs and ecological consequences. New Phytol 2012, 196:788-798.

51. Chen J-W, Zhang Q, Cao K-F: Inter-species variation of photosynthetic and xylem hydraulic traits in the deciduous and evergreen Euphorbiaceae tree species from a seasonally tropical forest in south-western China. Ecol Res 2009, 24:65-73.

52. Zhang J-L, Cao K-F: Stem hydraulics mediates leaf water status, carbon gain, nutrient use efficiencies and plant growth rates across dipterocarp species. Funct Ecol 2009, 23:658-667.

53. Meinzer FC, Woodruff DR, Domec J-C, Goldstein G, Campanello PI, Gatti MG, Villalobos-Vega R: Coordination of leaf and stem water transport properties in tropical forest trees. Oecologia 2008, 156:31-41.

54. Johnson DM, Woodruff DR, McCulloh KA, Meinzer FC: Leaf hydraulic conductance, measured in situ, declines and recovers daily: leaf hydraulics, water potential and stomatal conductance in four temperate and three tropical tree species. Tree Physiol 2009, 29:879-887.

55. Johnson DM, McCulloh KA, Woodruff DR, Meinzer FC: Hydraulic safety margins and embolism reversal in stems and leaves: Why are conifers and angiosperms so different? Plant Sci 2012, 195:48-53.

56. Blackman CJ, Brodribb TJ, Jordan GJ: Leaf hydraulic vulnerability is related to conduit dimensions and drought resistance across a diverse range of woody angiosperms. New Phytol 2010, 188:1113-1123.

57. Sellin A, Kupper P: Effects of light availability versus hydraulic constraints on stomatal responses within a crown of silver birch. Oecologia 2005, 142:388-397.
58. McDowell NG: Mechanisms linking drought, hydraulics, carbon metabolism, and vegetation mortality. Plant Physiol 2011, 155:1051-1059.

59. Sellin A, Eensalu E, Niglas A: Is distribution of hydraulic constraints within tree crowns reflected in photosynthetic water-use efficiency? An example of Betula pendula. Ecol Res 2010, 25:173-183.

60. Gornall JL, Guy RD: Geographic variation in ecophysiological traits of black cottonwood (Populus trichocarpa). Can J Bot 2007, 85:1202-1213.

61. Brown JD: Statistics Corner. Questions and answers about language testing statistics: Effect size and eta squared. Shiken JALT Test Eval SIG News/ 2008, 12:38-43.

doi:10.1186/1471-2229-14-72

Cite this article as: Sellin et al:: Rapid and long-term effects of water deficit on gas exchange and hydraulic conductance of silver birch trees grown under varying atmospheric humidity. BMC Plant Biology 2014 14:72.

\section{Submit your next manuscript to BioMed Central and take full advantage of:}

- Convenient online submission

- Thorough peer review

- No space constraints or color figure charges

- Immediate publication on acceptance

- Inclusion in PubMed, CAS, Scopus and Google Scholar

- Research which is freely available for redistribution 